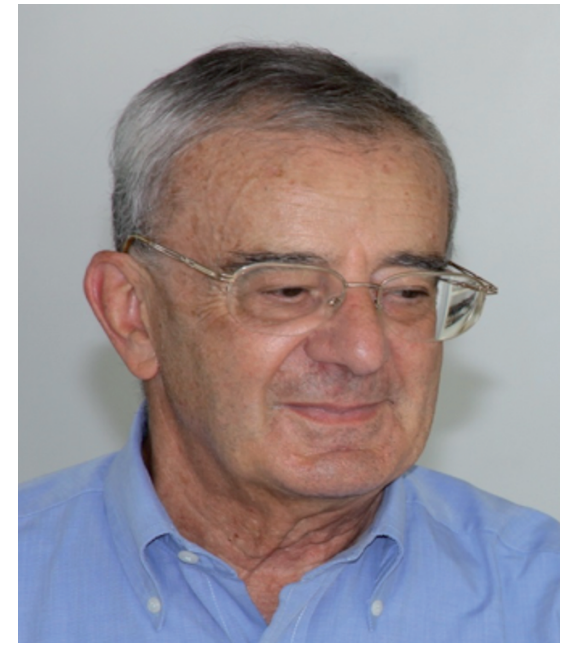

\section{IN MEMORY OF ETTORE GRIMALDI}

Ettore Grimaldi (1934-2015) was one of the brightest and active ichthyologists in Italy. He was a man of great enthusiasm, boundless energy and great curiosity. He was a person with an open mind.

He originally visited the Institute of Pallanza in June 1957 as a master student at the Faculty of Veterinary Medicine at the University of Milan. He was formally called back by the Director Vittorio Tonolli, as a research assistant in 1962. Together with Dr. Andrè Berg, a scientists of the EURATOM (now Joint Research Center of European Union), and life-long good friend, he led a team studying fish ecology and food web interactions in Lake Maggiore. At the time, this northern Italian lake was facing eutrophication and chemical pollution.

Ettore's studies were fundamental in defining the main characteristics of the native and introduced pelagic species of Lake Maggiore. His publications on the biology of the fish in this large lake still represent a milestone in the national and international literature. Ettore was also scientifically very active in the field of fish parasitology and ichthyo pathology of both, wild and reared fish, a passion which stemmed from his universities studies. More broadly he was a qualified limnologist. Ettore was the Director of the Italian Institute of Hydrobiology of Pallanza from 1979 to 1983 . He then moved to a permanent position as Associate Professor of Hydrobiology and Fish Rearing at the University of Milan, Faculty of Veterinary Medicine.

Ettore was more than, simply, a scientist. During his tenure at the Italian Institute of Hydrobiology, he was appointed by Prof. Tonolli as director of the Consortium for the Fishery of Lake Maggiore, an Institution belonging to the Ministry of Agriculture and Forestry and a position he covered from 1964 to 1971 . He became involved with the world of lake fisheries and continued to be actively involved until death. Ettore was involved in many activities and roles of institutional responsibility in the management of fish and fisheries in Italian waters, which included lakes to transitional and marine waters. For example, he was a member, from 1979 to his death, heading it from 1990 to 2005, of the International Commission for the protection of Italian-Swiss Waters, the Consortium for the Fishery of the Regione Veneto and he was the Secretary of the Italian-Swiss Committee for Fishery.

Ettore had the capacity to transfer his contagious enthusiasm, seriousness and knowledge, to a large audience. He dedicated part of his life to ongoing education and educational activities such as book writing and attending conferences and lectures at Universities, regional and $\mathrm{Na}-$ tional Institutions.

Ettore was a husband, a father and a grandfather. $\mathrm{He}$ was also a father figure to many of his students and colleagues, a man of great humanity, and sense of humour.

Ciao, Ettore.

\section{Pietro Volta, Alcide Calderoni CNR-ISE Largo Tonolli 50 28922 Verbania Pallanza (VB), Italy}

\section{SOME SELECTED PUBLICATIONS}

Berg A, Grimaldi E, 1966. Biologia dell'agone (Alosa ficta lacustris) del Lago Maggiore. Mem. Ist. Ital. Idrobiol. 20:41-83.

Berg A, Grimaldi E, 1965. Biologia delle due forme di coregone (Coregonus sp.) del Lago Maggiore. Mem. Ist. Ital. Idrobiol. 18:25-196.

Borroni I, Grimaldi E, 1973. Frequenza dell'infestione muscolare da larve plerocercoidi di Diphyllobotrium latum (Cestoda: Pseudophyllidaeo) nel pesce persico (Perca fluviatilis) dei laghi italiani (Anni 1968-1970). Riv. Parassit. 34:45-54.

Ghittino P, Grimaldi E, 1972. Appraisal of fishing waters and their fish populations in Italy. Riv. It. Piscic. Ittiop. A. 7:77-79.

Ghittino P, Grimaldi E, 1972. Country reports on fish disease and their control and national and international traffic of live fish and fish eggs. Report from Italy. Riv. It. Piscic. Ittiop. A. 7:87-90.

Giavenni R, Finazzi M, Poli G, Grimaldi E, 1980. Tubercolosis in marine tropical fishes in an aquarium. J. Wildlife Dis. 16:161-168.

Giussani G, Borroni I, Grimaldi E, 1976. Role of unionized ammonia in predisposing gill apparatus of Alburnus alburnus alborella to fungal and bacterial diseases. Mem. Ist. Ital. Idrobiol. 33:161-175.

Grimaldi E, 1965. Frequenza delle malformazioni nella popolazione di coregone bondella (Coregonus sp.) del Lago Maggiore. Mem. Ist. Ital. Idrobiol. 19:95-99.

Grimaldi E, 1967. Mortalità preriproduttiva nel pesce persico (Perca fluviatilis) di prima maturazione del Lago Maggiore e sua influenza sulla struttura di popolazione della specie. Mem. Ist. Ital. Idrobiol. 22:105-116.

Grimaldi E, 1969. Significato e limiti dei ripopolamenti ittici alla luce della biologia. Riv. Ital. Piscic. Ittiop. A. 4: 13-20.

Grimaldi E, 1971. Episodi di mortalità massiva a carico delle popolazioni di alborella (Alburnus alborella) dei laghi del Nord-Italia, provocati da una infezione branchiale sostenuta da miceti del genere Branchiomyces. Riv. It. Piscic. Ittiop. A. 6:1-14.

Grimaldi E, 1971. Fisiologia dei pesci e rifornimento idrico: qualche considerazione di interesse pratico per il piscicoltore. Riv. It. Piscic. Ittiop. A. 6:85-88. 
Grimaldi E, Albertarelli M, 1977. A pesca col professore. Mondadori, Milano: $283 \mathrm{pp}$.

Grimaldi E, 1972. Lago Maggiore: effects of exploitation and introductions on the salmonid community. J. Fish. Res. Board Can. 29:777-785.

Grimaldi E, 1972. Trascurabile ruolo dei Copepodi nel regime alimentare dei pesci planctofaghi del Lago Maggiore. Riv. It. Piscic. Ittiop. 7:3-5.

Grimaldi E, 2001. I pesci del Lago Maggiore e degli altri laghi prealpini Orta, Lugano, Como, Iseo, Garda. E. Alberti, Verbania: $159 \mathrm{pp}$.
Grimaldi E, Numann W, 1972. The future of salmonid communities in the European subalpapine lakes. J. Fish. Res. Board Can. 29:931-936.

Peduzzi R, De Meuron PA, Grimaldi E, 1983. Investigation of Aeromonas isolated from water: a serological study using Ouchterlony and immunoelectrophoresis techniques. Experientia 39:924-926.

Spreafico E, Berg A, Grimaldi E, 1974. Accrescimento e fecondità del coregone bondella (Coregonus sp.) considerati in rapporto alle modificazioni trofiche del Lago Maggiore. Mem. Ist. Ital. Idrobiol. 31:205-220. 